Farnborough), Mr. D. Firth (National Engineering Laboratory, Glasgow), Mr. H. A. Gebbie (National Physical Laboratory), Dr. K. W. Mangler (Royal Aircraft Establishment, Farnborough), Dr. D. McLean (National Physical Laboratory), Dr. F. Pasquill (Meteorological Office), Mr. P. M. Woodward (Royal Radar Establishment, Malvern), Dr. N. Hogben (National Physical Laboratory), Miss E. A. Killick (Admiralty Surface Weapons Establishment), Mr. G. F. Miller (National Physical Laboratory), Dr. T. H. Simpson (Torry Research Station, Aberdeen), Dr. W. T. Stearn (Department of Botany at the British Museum (Natural History)), Dr. T. A. Stuart (Freshwater Fisheries Laboratory, Pitlochry), Mr. W. T. Duerdoth (Post Office Research Station, Dollis Hill), Mr. D. L. Richards (Post Office Research Station, Dollis Hill), Mr. L. Islip (National Gas Turbine Establishment, Pyestock), Dr. T. E. Gibson (Central Veterinary Laboratory, Weybridge), Dr. R. Bullough (Atomic Energy Research Establishment, Harwell), Mr. M. F. A. Harrison (Culham Laboratory), Dr. M. J. Makin (Atomic Energy Research Establishment, Harwell), Dr. A. Robertson (Unit of Animal Genetics, University of Edinburgh), Dr. J. R. Bendall (Meat Research Institute, Cambridge), Dr. P. M. Biggs (Houghton Poultry Research Station, Huntingdonshire), Dr. L. C. Luckwill (Agricultural and Horticultural Research Station, Bristol), Mr. J. A. Nelder (National Vegetable Research Station, Warwick), Dr. E. C. Reeve (Unit of Animal Genetics, University of Edinburgh), Dr. A. S. Laughton (National Institute of Oceanography), Dr. V. C. Reddish (Royal Observatory, Edinburgh).

\section{Glass International}

The British Glass Industry Research Association is planning to become international, providing that British industry does not suffer, according to the Association's Eleventh Annual Report. The organization, which is now composed of 100 member companies, has decided to allow foreign companies to "enjoy the advantages of membership of the Association".

The advantages include the results of research carried out by the scientific staff of the Association. Last year much progress was made in furnace design by a comparison of existing plant. There is also work on regenerators, automation of the batch-house, mathematical studies of heat transfer during glass forming, new techniques for chemical analyses and the analysis of costs. The association also provides an information service which issues a Digest of Information and Patent Review once a month; last year it was expanded to include a collection of statistical data related to technical aspects of glass manufacture. The Association last year also did a great deal of consultative work for its members, acted as test authority for four British Standards-land transport, cooker doors, gauge glasses for pressure vessels, and ships' windows--and assisted members in statistical analyses of their data; they employ two statisticians and have acquired an Elliott 903 computer to help members in the use of such modern management techniques as critical path procedures. With an income last year of more than $£ 137,000$, a balance of $£ 16,000$ and more income if overseas firms decide to join, the Association is in a very good position for the expansion it seems to foresee.

\section{Parliament in Britain}

THE joint parliamentary secretary to the Treasury, Mr. P. Shore, said in the House of Commons on October 18 that useful progress was being made in the three year programme on desalination which the Atomic Energy Authority was carrying out in association with industry on a planned expenditure of $£ I \cdot 5$ million. The economies of desalted water varied from place to place. Desalted water was already available on a commercial scale from plants built overseas by British industry and Mr. Shore agreed that there was very considerable export potential for such plant, particularly in the arid lands of the Middle East and, to some extent, in Latin America. In Britain, although research would continue for some years to come, we must look to conventional supplies because they were much cheaper. The possibility of erecting a pilot desalination plant in conjunction with a coastal nuclear power station would be kept in mind. About 50 per cent of all installed desalination plant had been exported from Britain.

The Minister of Overseas Development, Mr. A. Bottomley, stated in a written answer in the House of Commons on October 18 that the $£ 2.13$ million in the Civil Estimates 1966-67 to be spent on the promotion of science and technology for the benefit of developing countries includes grants to governments, universities or research organizations either in Britain or overseas. Of the total, $£ 724,000$ was for agriculture, $£ 154,000$ for veterinary science, $£ 100,000$ for fisheries, $£ 110,000$ for pesticides, $£ 385,000$ for medical purposes, $£ 125,000$ for trypanosomiasis, $£ 125,000$ for social and economic science, $£ 243,000$ for roads and $£ 65,000$ for building. $£ 22,000$ was for floras, $£ 13,000$ for forestry, $£ 10,000$ for coconut centres and $£ 2,000$ for nature conservancy.

of this total, 29 per cent was spent in Britain. The largest single allocations were as follows: East Africa Natural Resources Research Council, $£ 224,000$; East Africa Medical Research Council, $£ 127,000$; East Africa Industrial Research Council, $£ 19,000$; Agricultural Research Council of Central Africa, $£ 94,000$; Regional Research Council of the West Indies, $£ 142,000$; Tropical Fish Culture Research Institute, Malacca, $£ 53,000$; Tropical Section of Road Research Laboratory, $£ 243,000$; and Overseas Division of Building Research Station, $£ 65,000$.

IN a written reply in the House of Commons on October 19, the Minister of State, Department of Education and Science, Mr. C. Roberts, stated that research on foot and mouth disease was concentrated at the Animal Virus Research Institute, Pirbright, comprising about three-quarters of the work of that Institute at an expenditure estimated at $£ 582,000$ in $1966-67$. Most of the work was concerned with long-term studies of the disease and the various strains of virus which cause it.

In a written answer on October $19, \mathrm{Mr}$. Roberts stated that 12 of the 32 Natural Nature Reserves in Scotland contained lochs varying in size from 1 to over 3,000 acres. Research was at present being undertaken on Loch Loven, Loch Druidibeg, Morton Lochs, and part of Loch Lomond, but this was not primarily concerned with the discovery of new species of flora and fauna; none had in fact recently been found. 